\title{
Nitrogén, réz és molibdén kölcsönhatások repcére (Brassica napus L.)
}

\author{
KÁDÁR IMRE \\ MTA ATK Talajtani és Agrokémiai Intézet, Budapest
}

\section{Bevezetés és irodalmi áttekintés}

A repce trágyaigényes kultúra. Érzékeny az aszályra, tápelem-hiányra és a rovarkártevőkre egyaránt. Hagyományosan a trágyázott fekete ugarba került a jövedelmezőbb termelés érdekében, mert CSERHÁTI (1901) szerint „a sovány földben repczét termelni kárba veszett fáradság." Sokoldalúan hasznosítható: szerepelhet a zöld takarmánykeverékekben, legeltethető, zöldtrágyanövény, karógyökere a talaj szerkezetét javíthatja, olaja keresett és drága, pogácsája fehérjében és lizinben gazdag. Kiváló előveteménye a búzának, gépesítése a kalászosok gépeivel megoldható.

A repce ősszel 5-8 leveles hajtást képez, mely földhöz lapult rozettát alkot. Tavasszal részbeni levélváltást követően indul meg a föhajtás, mely elágazik. Az elágazással (2-10 db) arányos a virágok száma, mert idővel az alsóbbrendủ elágazások is virágoznak. A ritka vetésnél több elágazás képződik. A virágok 520\%-a termékenyül meg és ebből 40-60\% képez becőt, melyek száma növényenként akár a 200-at is elérheti. A mellékhajtásokon 19-24 db magszámmal kevesebb becő, a becőkben pedig kevesebb mag képződik, mint a föhajtáson. Az 1000-mag tömege 3-6 g, a gyökér tömege 30-40 \%-a a szárnak (LÁNG 1976, EÖRI 2001)

A tápanyagellátás befolyásolja a termésszerkezetet. Változhat a tőszám, a növényenkénti elágazások és becők száma, a becőnkénti magszám, az 1000magtömeg és az olajtartalom. Részben már ősszel eldől a termés sorsa. Az oldalelágazások száma kb. az öszi levélszámmal azonos. Régi megfigyelés szerint "ahány levéllel megy a repce a télbe, annyi q terméstöbblettel fizet." A gyengén fejlett őszi állomány már nem hozhatja be fejlődésbeli hátrányát tavasszal. A terméselemek között kiegyenlítődésre való törekvés figyelhető meg: negatív kapcsolat van a tőszám és elágazások száma, a becőszám és a becőbeni magszám, a magszám és az 1000-magtömeg, valamint a mag olajtartalma és fehérje tartalma között. (HORVÁTH 2016).

A repce ÉNy-Európa fő olajnövénye, ahol az óceáni hatások uralkodnak. A hosszúnappalos növény hủvös, párás nyarú vidékeken díszlik igazán, mert érés idején is vízigényes. Egyaránt igényli a talaj és a levegő nedvességtartalmát. Itt az újabb fajtákkal és agrotechnikával a 3-4 $\mathrm{t}$ ha ${ }^{-1}$ magtermés elérhető és a legnagyobb olajhozamot biztosítja hektáronként. A szalma + becő tömege a mag 2-3-szorosa (PRJANISNYIKOV 1931, MÁtÉ-PePó 2005).

A kontinentális, forró és száraz nyarú tájakon a tenyészidő generatív szakasza lerövidül, az érés gyorsul és a magtermés lecsökken. Aszály esetén kényszerérés

Postai cím: KÁDÁR IMRE, MTA ATK TAKI, 1022 Budapest, Herman Ottó út 15.

E-mail: kadar.imre@agrar.mta.hu 
következik be, a vegetatív részek (gyökér, szár, lomb) mobilizálható tápelemkészlete nem juthat a magba. Ilyenkor csökken a megtermékenyülés is, tehát nemcsak kisebb, hanem kevesebb mag képződik. Itthon más fajtákra van szükség, más agrotechnikát, trágyázást kell folytatnunk. A Ny-európai tapasztalatok nem vehetők át minden további nélkül. Hazai viszonyaink között pl. a mag és a melléktermék aránya tággá válik, alföldi jellegü vidékeken a szalma+becő tömege a maghozam 4-6-szorosa is lehet. Ebböl adódóan eltérö lesz a növény fajlagos tápelemtartalma illetve trágyaigénye stb. (KÁDÁR et al. 2001a).

A repce számára az altalaj minősége is fontos, karógyökere mélyre hatol. A gyökér azonban gyenge felépítésü, a növény könnyen kinyühető, ezért már kezdetben sok felvehető tápelemet igényel. A P-hiány gátolja a korai fejlődést, kitolódik az érés, a magtermés visszaszorul. A szuperfoszfát összetételénél fogva kielégítheti a repce P-, S- és részben Ca-igényét. Ny-Európa müvelt talajai P-ral feltöltöttek, az újkori irodalom érdemi $\mathrm{P}$-hatásokról nem tudósit. A jelentős vegetatív tömeg sok káliumot igényel, ennek ellenére K-trágya hatások itthon ritkák. A repcét általában kötöttebb, mélyrétegủ talajokon termesztik, az ilyen talajok K-szolgáltatása általában kielégítő. A felvett $\mathrm{K}$ döntő része visszakerül a talajba a leszántott mellékterméssel.

Mezőföldi karbonátos csernozjom talajon beállított mütrágyázási tartamkísérletünk (KÁDÁR et al. 2001a) 11. évében, 1984-ben Yet Neuf francia erukasav-szegény repcét termesztettünk. Kora tavasszal tőrózsás korban az együttes NPK trágyázás hatására a repce borítottsága megkétszereződött és ezzel együtt a gyomborítás közel a felére csökkent. Érés kezdetén, július elején igazolható volt a gyomfajok számának csökkenése A K-trágyázás eredményeképpen az elágazások és a növényenkénti becők száma nőtt. Az N-trágyázás egymagában nem eredményezett mérhető változást.

Az intenzív NPK adagolás közel kétszeresére növelte a maghozamot és a melléktermés mennyiségét. A virágzástól a teljes érésig tartó szárazság miatt kényszerérés következett be és kis magtermések képződtek. Ebből adódóan a szár/mag tömegarány 6-8 közöttire tágult. A növekvő N-trágya adagok csökkentették a mag olajtartalmát. Az együttes NPK kezeléssel az olajhozam a kontrollon mért 336-ról $738 \mathrm{~kg} \cdot \mathrm{ha}^{-1}$-ra emelkedett. Igazolható terméstöbbleteket a $150-200 \mathrm{mg} \cdot \mathrm{kg}^{-1} \mathrm{AL}-\mathrm{P}_{2} \mathrm{O}_{5}$, illetve AL- $\mathrm{K}_{2} \mathrm{O}$ ellátottság felett már nem kaptunk. A túlzottnak minősíthető NPK-adagok hatására némi termés- és olajhozam többletet eredményeztek (KÁDÁR et al. 2001b).

A túlzott NPK trágyázásban részesült talajon kaptuk a maximális termést. Ez tekintélyes mennyiségü tápelemet vont ki a talajból: $238 \mathrm{~kg} \mathrm{~N}, 230 \mathrm{~kg} \mathrm{~K}_{2} \mathrm{O}$-val egyenértékủ K, $210 \mathrm{~kg} \mathrm{CaO}$-al egyenértékủ Ca, $98 \mathrm{~kg} \mathrm{P}_{2} \mathrm{O}_{5}$-el egyenértékü $\mathrm{P}, 65 \mathrm{~kg}$ MgO-val egyenértékü Mg, $39 \mathrm{~kg} \mathrm{Na}, 1 \mathrm{~kg} \mathrm{Fe}, 600$ g Mn, 170 g Zn és $29 \mathrm{~g} \mathrm{Cu}$ hektáronként. A N 36\%-a, P 61\%-a, Mg 70\%-a, Na és Ca 90\%-a, illetve a K 92\%-a a szárban akkumulálódott és így nem került el a tábláról a betakarítást követően. Az 1,8 t/ha magterméssel hektáronként „,csak” $93 \mathrm{~kg} \mathrm{~N}$-el, $27 \mathrm{~kg} \mathrm{P}_{2} \mathrm{O}_{5}$-al egyenértékü P-al., 20 kg CaO-al egyenértékü Ca-al, 17 kg K2O-val egyenértékü K-al, $15 \mathrm{~kg}$ MgO-al egyenértékủ Mg-al és 4 kg Na-al szegényedett a talaj. Kielégítően ellátott 
termőhelyen tehát elégséges a $\mathrm{N}$ és $\mathrm{P}$ magterméssel elvont mennyiségeit pótolni. A repce számára kielégítő N-ellátottságot biztosítanak azok a talajok, amelyek 0-60 cm-es talajrétegében 100-150, illetve 0-90 cm-es talajrétegében 150-200 kg.ha-1 $\mathrm{NO}_{3}-\mathrm{N}$ mutatható ki vetés előtt, vagy kora tavasszal, (KÁDÁR et al. 2001b).

A $\mathrm{Cu}$ közismerten komplexképző tulajdonsággal rendelkezik, a talajkolloidokhoz és a humuszvegyületekhez erősen kötődik. Ezért védett a kilúgzástól a talajban. A kétértékủ kationok adszorpciós energiája az alábbi sorrendet követi: $\mathrm{Cu}>\mathrm{Pb}>\mathrm{Ni}>\mathrm{Co}>\mathrm{Zn}>\mathrm{Ca}$. A Cu növénybeni mozgása is gátolt, így a tenyészidő során fellépő esetleges Cu-hiány a fiatal hajtásokban, levelekben jelentkezik. A Cu szerepet játszik a fehérjeszintézisben. A bőséges Ntrágyázáskor a Cu-igény megnő, illetve gyakrabban felléphet a Cu-hiány. Különösen száraz években a Cu-szegény homokos, lápos és az erősen meszes, humuszos talajokon. BERGMANN (1992) szerint a $\mathrm{Cu}$ hiányára fokozottan érzékenyek a kalászos kultúrák és a napraforgó. A növényi felvétel a termésszinttől, növényfajtól és a talaj Cu-kínálatától függően 20-150 g/ha/év mennyiség között változhat.

BOWEN (1979) szerint a $\mathrm{Cu}$ a talajban átlagosan $26 \mathrm{mg} \mathrm{kg}^{-1}$, a felszíni édesvizekben $3 \mu \mathrm{g} \mathrm{l}^{-1}$ míg a tengervízben csupán $0,25 \mu \mathrm{g} \mathrm{l}^{-1}$ koncentrációban mutatható ki. Saját nem publikált méréseink szerint a TIM pontok (Talajinformációs Monitoring Rendszer) talajainak talajvizében $(\mathrm{n}=41)$ 0,2-20 $\mu \mathrm{g}$ $1^{-1}$, a Balaton vizében 3-5 $\mu \mathrm{g} \mathrm{I}^{-1}$, esővíz mintákban 4-20 $\mu \mathrm{g} \mathrm{l^{-1 }}$ Cu-t találtunk. A hazai szenek vizsgálataink szerint $(\mathrm{n}=12) 7-36 \mathrm{mg} \mathrm{kg}^{-1}$, míg a budapesti agglomeráció területén közelmúltban gyüjtött szálló por $100-613 \mathrm{mg} \mathrm{kg}^{-1} \mathrm{Cu}-$ tartalmaztak. Utóbbi erős szennyezésnek minősül, amennyiben a talajokra megadott szennyezettségi küszöb a hazai szabályozás szerint $75 \mathrm{mg} \mathrm{kg}^{-1}$ a 10/2000. (VI.2.) rendelet szerint.

PAIS (1980) szerint a Cu esszencialitását 1925-ben igazolták először. A Cu hiánya is elterjedt. A gabonafélék tőzeges talajon gyakran nem fejlesztenek kalászt. Felléphet másodlagos vagy indukált Cu-hiány rétláp talajokon a Mo-felesleg miatt. TÖLGYESI (1965) vizsgálatai rámutattak, hogy pl. a keszthelyi lápon termett növényekben egyidejüleg fennállhat a $\mathrm{Cu}$ hiánya és a Mo többlete. A szervesanyagban gazdag talajok ugyanis Mo-ban is gazdagok, míg a rezet megkötik. Az élettanilag kívánatos 5-10 körüli $\mathrm{Cu} / \mathrm{Mo}$ arány a takarmányban akár 0,1-0,2 értékre szükülhet Mo-toxikózist okozva. A legeltetett juh és marha anémiás lépbetegségét a Cu-hiányra, illetve a Mo-bőségre vezetik vissza.

A Mo hiányt ritkán sikerül kimutatni növényben, állatban vagy emberben, mert az élővilág rendkívül kis mennyiségben igényli. A túlsúlya jelenthet problémát. A talajban nem kötődik meg, így arid vidékeken a Na, B, Se és egyéb mobilis elemekkel együtt a feltalajban dúsul. A talaj/növény rendszerben a szürő nem müködik, a növény hiperakkumulátorként halmozza fel a tömegárammal bejutó Mo-t. A Mo túlsúlya a takarmányban, legelőfúben mérgezést, molibdenózist, a legelőhasmenés tünetegyüttesét okozza. A vizet áteresztő kilúgzásos talajokon nem lép fel Mo toxicitás. Az NxCuxMo kölcsönhatásokat elöző munkánkban részben taglaltuk (KÁDÁR és CSATHÓ 2017). 


\section{Anyag és módszer}

A N x Cu kölcsönhatásokat vizsgáló kéttényezős kísérletet 1988 tavaszán állítottuk be az MTA TAKI nagyhörcsöki kísérleti telepén. A kísérlet talaja löszön képződött meszes csernozjom mely a kísérlet beállítása előtt 1988. március elején végzett talajvizsgálataink szerint mintegy $5 \% \mathrm{CaCO}_{3}$-ot és $3 \%$ humuszt tartalmazott a szántott rétegben. A pH(KCl) = 7,3; az AL- $\mathrm{P}_{2} \mathrm{O}_{5} 128 \mathrm{mg} \cdot \mathrm{kg}^{-1}$, AL$\mathrm{K}_{2} \mathrm{O} 243 \mathrm{mg} \cdot \mathrm{kg}^{-1}$, KCl-Mg 150-180 mg $\mathrm{kg}^{-1}$, az EDTA-Mn $127 \mathrm{mg} \cdot \mathrm{kg}^{-1}$, az EDTA$\mathrm{Cu} 2-3 \mathrm{mg} \cdot \mathrm{kg}^{-1}$, EDTA-Zn 1-2 $\mathrm{mg} \cdot \mathrm{kg}^{-1}$ értékekkel jellemezhetők. A KCl-oldható $\mathrm{NH}_{4}-\mathrm{N}$ 9, $\mathrm{NO}_{3}-\mathrm{N} 12 \mathrm{mg} \cdot \mathrm{kg}^{-1}$ a feltalajban. A BuZÁs I. et al. (Szerk.: 1979) által elfogadott módszerek és határértékek alapján ezek az adatok a talaj jó $\mathrm{Ca}, \mathrm{Mg}, \mathrm{K}$, $\mathrm{Mn}$; kielégítő $\mathrm{Cu}$, valamint gyenge $\mathrm{P}$ és Zn ellátottságáról tanúskodnak. A talajvíz szintje 13-15 m mélyen helyezkedik el, a terület aszályérzékeny. Éghajlata az Alföldéhez hasonlóan szárazságra hajló, átlagos középhőmérséklete $11^{\circ} \mathrm{C}$, éves átlagos csapadékösszege $576 \mathrm{~mm}$.

A kísérlet osztott parcellás (split-plot) elrendezésü $4 \mathrm{Nx} 3 \mathrm{Cu}=12$ kezeléssel és 3 ismétléssel, összesen 36 parcellával. A parcellák mérete $4,9 \times 15=73,5 \mathrm{~m}^{2}$ volt. Az alaptrágyázás évente $100 \mathrm{~kg} \cdot \mathrm{ha}^{-1} \mathrm{P}_{2} \mathrm{O}_{5}$ és $100 \mathrm{~kg} \cdot \mathrm{ha}^{-1} \mathrm{~K}_{2} \mathrm{O}$ adagot jelentett szuperfoszfát és kálisó formájában. A N-t 25\%-os pétisó $\left(\mathrm{Ca}-\mathrm{NH}_{4} \mathrm{NO}_{3}\right)$, a $\mathrm{Cu}$ trágyát 25,5\%-os $\mathrm{CuSO}_{4} \times 5 \mathrm{H}_{2} \mathrm{O}$ formában alkalmaztuk. A PK mütrágyákat és a $\mathrm{N}$ felét az elővetemény lucerna törésére szórtuk ki 1987 öszén és leszántottuk, míg a $\mathrm{N}$ másik felét és a $\mathrm{CuSO}_{4}$ trágyát 1988 tavaszán kevertük a talajba vetés előtt.

Az 5. évben 1992 tavaszán a 15 m hosszú parcellákat megfeleztük és egy 1 mes úttal elválasztottuk. Az osztott parcellás (split-plot) elrendezésủ kísérletünk háromtényezőssé vált $4 \mathrm{~N} \times 3 \mathrm{Cu} \times 2 \mathrm{Mo}=24$ kezeléssel $\times 3$ ismétléssel $=72$ parcellával. A felezett parcellákra $48 \mathrm{~kg} \cdot \mathrm{ha}^{-1}$ Mo-t szórtunk ki N-fejtrágyával egyidőben. A Mo trágyát $\left(\mathrm{NH}_{4}\right)_{6} \mathrm{Mo}_{7} \mathrm{O}_{24} \cdot 4 \mathrm{H}_{2} \mathrm{O}$ formában adagoltuk. A $\mathrm{N}$ és a Mo sókat a következő napok csapadéka a talajba mosta. Tehát a Cu-trágyázás 1988-ban, Mo-trágyázás 1992-ben történt egyszeri alkalommal. A N, P és K mütrágyákat évente adtuk.

Vizsgált tényezők az alábbiak:

\begin{tabular}{lll} 
1. tényezö (föparcellák): & 2. tényezö (alparcellák): & 3. tényezö (al-alparcellák) \\
\cline { 2 - 3 } $\mathrm{N}_{0}=\mathrm{kontroll}$ & $\mathrm{Cu}_{0}=\mathrm{kontroll}$ & $\mathrm{Mo}=\mathrm{kontroll}$ \\
$\mathrm{N}_{1}=100 \mathrm{~kg} \cdot \mathrm{ha}^{-1} \cdot \mathrm{é}^{-1} \mathrm{~N}$ & $\mathrm{Cu}_{1}=50 \mathrm{~kg} \cdot \mathrm{ha}^{-1} \mathrm{Cu}$ 1988-ban & $\mathrm{Mo}=48 \mathrm{~kg} \cdot \mathrm{ha}^{-1}$ 1992-ben \\
$\mathrm{N}_{2}=200 \mathrm{~kg} \cdot \mathrm{ha}^{-1} \cdot \mathrm{é}^{-1} \mathrm{~N}$ & $\mathrm{Cu}_{2}=100 \mathrm{~kg} \cdot \mathrm{ha}^{-1} \mathrm{Cu} \mathrm{1988-ban}$ &
\end{tabular}

$\mathrm{N}_{3}=300 \mathrm{~kg} \cdot \mathrm{ha}^{-1} \cdot \mathrm{év}^{-1} \mathrm{~N}$

A kísérlet 1. évében 1988-ban tavaszi árpa, 1989-ben őszi búza, 1990-ben őszi árpa, 1991-ben kukorica, 1992-ben triticale, 1993-ban burgonya, 1994-ben zab, 1995-ben rozs, 1996-1999-ig lucerna volt a termesztett növény. A kísérlet 15 éven át folyt, a növényi sorrendet 1988-2003 között az 1. táblázat ismerteti. 


\section{1. táblázat}

A N x Cu tartamkísérlet növényi sorrendje 1988-2003 között (Mészlepedékes csernozjom vályogtalaj, Nagyhörcsök, Mezőföld)

\begin{tabular}{|c|c|c|c|c|c|}
\hline $\begin{array}{l}\text { Kísérlet } \\
\text { éve (1) }\end{array}$ & $\begin{array}{l}\text { Növényfaj } \\
\text { (forgó) (2) }\end{array}$ & $\begin{array}{c}\text { Fajta } \\
\text { (hibrid) (3) }\end{array}$ & $\begin{array}{c}\text { Kísérlet } \\
\text { éve (1) }\end{array}$ & $\begin{array}{l}\text { Növényfaj } \\
\text { (forgó) (2) }\end{array}$ & $\begin{array}{c}\text { Fajta } \\
\text { (hibrid) (3) }\end{array}$ \\
\hline 1988 & tavaszi árpa (4) & Opal & 1996 & lucerna(12) & Szarvasi-1 \\
\hline 1989 & öszi búza (5) & MV-15 & 1997 & lucerna(12) & Szarvasi-1 \\
\hline 1990 & őszi árpa (6) & MV-35 & 1998 & lucerna(12) & Szarvasi-1 \\
\hline 1991 & kukorica (7) & Pi 3732 & 1999 & lucerna(12) & Szarvasi-1 \\
\hline 1992 & triticale $(8)$ & Presto & 2000 & repce (13) & Wester \\
\hline 1993 & burgonya (9) & Desirée & 2001 & mák (14) & Kék Duna \\
\hline 1994 & $\mathrm{zab}(10)$ & Leanda & 2002 & $\begin{array}{l}\text { napraforgó } \\
\text { (15) }\end{array}$ & IHNK hibrid \\
\hline 1995 & $\operatorname{rozs}(11)$ & Kisvárdai-1 & 2003 & $\begin{array}{l}\text { tavaszi árpa } \\
\text { (4) }\end{array}$ & Orbit \\
\hline
\end{tabular}

Laboratóriumi vizsgálatok az MTA ATK Talajtani és Agrokémiai Intézetben történtek az alább ismertetett módszerekkel:

Növényelemzés: A bemért $0,5 \mathrm{~g}$ légszáraz anyaghoz $5 \mathrm{~cm}^{3} \mathrm{cc} \cdot \mathrm{HNO}_{3}+1 \mathrm{~cm}^{3}$ cc. $\mathrm{H}_{2} \mathrm{O}_{2}$ adagolása, majd 15 perces roncsolás a mikrohullámú berendezésben. Az ásványi elemek mérése ICP-AES készüléken. A $\mathrm{N}$ meghatározása: $0,5 \mathrm{~g}$ légszáraz anyaghoz $10 \mathrm{~cm}^{3}$ cc. $\mathrm{H}_{2} \mathrm{SO}_{4}+\mathrm{cc} \cdot \mathrm{H}_{2} \mathrm{O}_{2}$ szükség szerint adagolva az ISO 11261(1995), illetve a módosított KJELDAHL (1891) eljárással.

Talajelemzés: A $\mathrm{KCl}+$ EDTA oldható Cu-tartalmat, az AL-oldható PKtartalmat EGNÉR et al. (1960), valamint az $1 \mathrm{~mol} \mathrm{l}^{-1} \mathrm{KCl}$-kicserélhető $\mathrm{NH}_{4}-\mathrm{N}$ és $\mathrm{NO}_{3}$-N tartalmakat a MÉM NAK (1978), illetve BARANYAI et al. (1987) által ismert eljárásokkal vizsgáltuk. Az $\mathrm{NH}_{4}$-acetát+EDTA oldható ásványi elemeket LAKANEN és ERVIÖ (1971), a humuszt TYURIN (1937), az ammoniumlaktát+ecetsav oldható elemeket EGNÉr et al. (1960), az összes N-t az ISO 11261 (1995), illetve módosított KJELDAHL (1891) által ismertetettek alapján határoztuk meg.

A repce vetése 1999 . szeptember 14-én történt $2-3 \mathrm{~cm}$ mélyre, $5 \mathrm{~kg} \cdot \mathrm{ha}^{-1}$ vetőmagnormával, 24×5 cm-es kötésben. Gyomirtást, növényvédelmi beavatkozást nem végeztünk a tenyészidő alatt. A kombájnolásra június 26-án került sor. A terméseredményt a parcellák belső (nettó) területéről $\left(7 \times 2,1=14,7 \mathrm{~m}^{2}\right)$ betakarított termésböl számoltuk. 4-4 fm mintakévét vettünk parcellánként a főtermés és a melléktermés arányának megállapítása, illetve a laboratóriumi elemzés céljaira. A minták szárítását, cséplését, darálását a kísérleti telepen végezték. A repce 9,5 hónapos tenyészideje alatt az átlagos évnek megfelelően 435 $\mathrm{mm}$ csapadék hullott, de májusban mindössze $20 \mathrm{~mm}$, júniusban $10 \mathrm{~mm}$ eső esett. Ez az aszályos időszak a magképződést akadályozta és kényszeréréshez vezetett. 


\section{Kísérleti eredmények}

A repce a virágzás/érés generatív szakaszában, vagyis májusban és júniusban bekövetkezett aszály mérsékelt magtermést, depressziót okozott. A melléktermés/fötermés hányadosa ebből adódóan 4,6-ról 13-ra tágult. A Nkínálattal látványosan nőtt a szártermés, míg a becő- és a magtermés visszaesett a $\mathrm{N}$-kontrollnál mérthez képest. $\mathrm{N}$-trágyázás nélkül a maximális magtermés $2 \mathrm{t}$.ha ${ }^{1}$ volt, ami. a további $\mathrm{N}$-adagok hatására $0,8 \mathrm{t} \cdot \mathrm{ha} \mathrm{a}^{-1}$-ra zuhant (2. táblázat.)

\section{2. táblázat}

N-trágyázás hatása a repce légszáraz termésére 2000. 06.26-án (Mészlepedékes csernozjom vályogtalaj, Nagyhörcsök, Mezőföld)

\begin{tabular}{|c|c|c|c|c|c|c|}
\hline $\begin{array}{c}(1) \\
\text { N-szintek } \\
\text { kg·ha }^{-1} \cdot \\
\text { év }^{-1}\end{array}$ & $\begin{array}{c}(2) \\
\text { Szár } \\
\text { t·ha }\end{array}$ & $\begin{array}{c}(3) \\
\text { Becö } \\
\text { t·ha }\end{array}$ & $\begin{array}{c}(4) \\
\text { Együtt } \\
\text { t·ha }\end{array}$ & $\begin{array}{c}(5) \\
\text { Mag } \\
\text { t·ha }\end{array}$ & $\begin{array}{c}(6) \\
\text { Összesen } \\
\mathbf{t} \cdot \mathbf{h a}^{-1}\end{array}$ & $\begin{array}{c}(7) \\
\text { Melléktermés } \\
(8) \\
\text { Főtermés }\end{array}$ \\
\hline 0 & 5.0 & 2.2 & 7.2 & 2.0 & 9.2 & 4.6 \\
\hline 100 & 6,8 & 2,0 & 8,8 & 1,8 & 10,6 & 5,9 \\
\hline 200 & 7,8 & 2,0 & 9,8 & 1,4 & 11,2 & 8,0 \\
\hline 300 & 8,2 & 1,4 & 9,6 & 0,8 & 10,4 & 13,0 \\
\hline (9) $\mathrm{SzD}_{5 \%}$ & 0,6 & 0,4 & 0,6 & 0,2 & 0,6 & 2,0 \\
\hline (10) Átlag & 6,9 & 1,9 & 8,8 & 1,5 & 10,4 & 6,9 \\
\hline
\end{tabular}

\section{3. táblázat}

N-szintek hatása a légszáraz repceszár elemtartalmára 2000.06.27-én

(Mészlepedékes csernozjom vályogtalaj, Nagyhörcsök, Mezőföld)

\begin{tabular}{|c|c|c|c|c|c|}
\hline \multirow{2}{*}{$\begin{array}{c}(1) \\
\text { N-szintek } \\
\mathbf{k g} \cdot \mathbf{h a}^{-1} \text {. } \\
\text { év }^{-1}\end{array}$} & \multicolumn{5}{|c|}{$\mathbf{m g} \cdot \mathbf{k g}^{-1}$} \\
\hline & $\mathrm{Na}$ & $\mathbf{F e}$ & Mn & Zn & $\mathbf{B a}$ \\
\hline 0 & 460 & 78 & 53 & 8,8 & 7,3 \\
\hline 100 & 802 & 92 & 57 & 10,5 & 6,6 \\
\hline 200 & 1379 & 82 & 58 & 9,6 & 6,7 \\
\hline 300 & 1400 & 110 & 63 & 11,2 & 6,2 \\
\hline (2) $\mathrm{SzD}_{5 \%}$ & 400 & 12 & 6 & 2,0 & 0,4 \\
\hline (3) Átlag & 1010 & 90 & 58 & 10,0 & 6,7 \\
\hline
\end{tabular}

A N-adagokkal emelkedett a szárban a $\mathrm{Na}, \mathrm{Fe}, \mathrm{Mn}, \mathrm{Zn}$, illetve igazolhatóan mérséklödött a $\mathrm{Ba}$ koncentrációja a szárban (3. táblázat). A Cu beépülését a $\mathrm{N}$ és a $\mathrm{Cu}$ trágyázás egyaránt serkentette, míg a $\mathrm{Cd}$ esetében a $\mathrm{N}$ serkentő hatása mellett a 
$\mathrm{Cu}$ gátló hatása érvénysült (4. táblázat). Amint az 5. táblázatban megfigyelhető, hogy érvényesült a NxMo szinergizmus a $\mathrm{N}$ és a Mo egyaránt dúsul az aratáskori szárban és a magtermésben a $\mathrm{N}$ és a Mo kezelések nyomán.

\section{4. táblázat}

N x Cu szintek hatása a légszáraz repceszár Cu és Cd tartalmára 2000.06.27-én (Mészlepedékes csernozjom vályogtalaj, Nagyhörcsök, Mezőföld)

\begin{tabular}{|c|c|c|c|c|c|c|}
\hline \multirow{2}{*}{$\begin{array}{c}\text { (1) } \mathbf{C u -} \\
\text { szint } \\
\mathbf{k g} \cdot \mathbf{h a}^{-1}\end{array}$} & \multicolumn{4}{|c|}{ (2) N-szintek kg·ha' ${ }^{-1}$ év $^{-1}$} & \multirow{2}{*}{$\begin{array}{c}\text { (3) } \\
\text { SzD }_{5 \%}\end{array}$} & \multirow{2}{*}{$\begin{array}{c}\text { (4) } \\
\text { Átlag } \\
\end{array}$} \\
\hline & $\mathbf{0}$ & 100 & 200 & 300 & & \\
\hline \multicolumn{7}{|c|}{$\mathrm{Cu} \mathrm{mg} \cdot \mathrm{kg}^{-1}$} \\
\hline 0 & 2,30 & 2,63 & 2,60 & 2,81 & & 2,59 \\
\hline 50 & 2,28 & 2,52 & 2,82 & 3,21 & 0,46 & 2,71 \\
\hline 100 & 3,01 & 3,04 & 3,35 & 3,84 & & 3,31 \\
\hline $\mathrm{SzD}_{5 \%}$ & \multicolumn{4}{|c|}{0,50} & & 0,25 \\
\hline Átlag & 2,53 & 2,73 & 2,92 & 3,29 & 0,23 & 2,87 \\
\hline \multicolumn{7}{|c|}{$\mathrm{Cd} \mu \cdot \mathrm{kg}^{-1}$} \\
\hline 0 & 208 & 319 & 364 & 401 & & 323 \\
\hline 50 & 213 & 256 & 300 & 382 & 61 & 288 \\
\hline 100 & 223 & 246 & 301 & 342 & & 278 \\
\hline (3) $\mathrm{SzD}_{5 \%}$ & \multicolumn{4}{|c|}{44} & & 22 \\
\hline (4) Átlag & 215 & 273 & 321 & 375 & 30 & 296 \\
\hline
\end{tabular}

Megjegyzés: Magtermésben a Cu-tartalom 3,90\%-ról 4,96\%-ra nőtt igazolhatóan a Cutrágyázással

\section{5. táblázat}

N x Mo szintek hatása a légszáraz repceszár N és Mo tartalmára 2000.06.27-én aratáskor (Mészlepedékes csernozjom vályogtalaj, Nagyhörcsök, Mezőföld)

\begin{tabular}{|c|c|c|c|c|c|c|}
\hline \multirow{2}{*}{$\begin{array}{c}\text { (1) Mo- } \\
\text { szint } \\
\text { kg } \mathbf{h a}^{-1}\end{array}$} & \multicolumn{4}{|c|}{ (2) N-szintek kg $\cdot \mathbf{h a}^{-1} \cdot$ év $^{-1}$} & \multirow[b]{2}{*}{ (3) $\mathbf{S z D}_{\mathbf{5} \%}$} & \multirow[b]{2}{*}{ (4) Átlag } \\
\hline & $\mathbf{0}$ & 100 & 200 & 300 & & \\
\hline \multicolumn{7}{|c|}{$\mathrm{N} \%$} \\
\hline 0 & 1,22 & 1,36 & 1,69 & 2,02 & 0,24 & 1,57 \\
\hline 48 & 1,35 & 1,61 & 1,81 & 2,18 & 0,24 & 1,74 \\
\hline (3) $\mathrm{SzD}_{5 \%}$ & \multicolumn{4}{|c|}{0,20} & & 0,10 \\
\hline (4) Átlag & 1,29 & 1,49 & 1,75 & 2,10 & 0,12 & 1,66 \\
\hline \multicolumn{7}{|c|}{ Mo $\mathrm{mg} \cdot \mathrm{kg}^{-1}$} \\
\hline 0 & 1,4 & 1,5 & 1,4 & 1,8 & 0,3 & 1,5 \\
\hline 48 & 29,9 & 41,7 & 42,6 & 50,1 & 17,0 & 41,1 \\
\hline (3) $\mathrm{SzD}_{5 \%}$ & \multicolumn{4}{|c|}{12,8} & & 6,4 \\
\hline (4) Átlag & 15,6 & 21,6 & 22,0 & 26,0 & 8,5 & 21,3 \\
\hline
\end{tabular}

Megjegyzés: Mo-trágyázással a mag N-tartalma is igazolhatóan emelkedett 
A repce átlagos elemtartalmának és elemfelvételének adatait a 6. táblázatban tanulmányozhatjuk. A szár + becő $8,8 \mathrm{t} \cdot \mathrm{ha}^{-1}$ mellékterméssel és $1,5 \mathrm{t} \cdot \mathrm{ha}^{-1}$ magterméssel számolhatunk. A bemutatott eredmények szerint fóként a magtermésben dúsult a $\mathrm{N}, \mathrm{P}, \mathrm{Mg}, \mathrm{Zn}, \mathrm{Cu}$, Mo, Se és a Co, melyek a szemképződés fontos elemeinek tekinthetők. Ami a földfeletti biomasszába épült mennyiségeket illeti látható, hogy a melléktermés tárolta az elemek nagyobb tömegét. Leszántásával a felvett elemek jórészt visszajutnak a talajba. A repce tápelemigényes kultúra. A kivont N 206 kg, Ca 172 kg, K 142 kg, S 78 kg, P 39 kg (89 kg $\mathrm{P}_{2} \mathrm{O}_{5}$ ), Mg $32 \mathrm{~kg}$, Na 8-9 kg mennyiségnek adódott hektárra vetítve.

\section{6. táblázat}

A repce átlagos elemtartalma és elemfelvétele 2000.06.27-én aratáskor (Mészlepedékes csernozjom vályogtalaj, Nagyhörcsök, Mezőföld)

\begin{tabular}{|c|c|c|c|c|c|c|c|}
\hline \multirow{2}{*}{$\begin{array}{l}(1) \\
\text { Elem } \\
\text { jele }\end{array}$} & \multirow{2}{*}{$\begin{array}{c}\text { (2) } \\
\text { Mérték- } \\
\text { egység }\end{array}$} & \multicolumn{2}{|c|}{ (3) Elemtartalom } & \multirow{2}{*}{$\begin{array}{c}\text { (2) } \\
\text { Mérték- } \\
\text { egység }\end{array}$} & \multicolumn{3}{|c|}{ (6) Elemfelvétel } \\
\hline & & $\begin{array}{c}\text { (4) } \\
\text { Szár+becő }\end{array}$ & $\begin{array}{c}(5) \\
\text { Mag }\end{array}$ & & $\begin{array}{c}\text { (4) } \\
\text { Szár+becő }\end{array}$ & $\begin{array}{c}(5) \\
\text { Mag }\end{array}$ & $\begin{array}{c}(7) \\
\text { Együitt }\end{array}$ \\
\hline $\mathrm{N}$ & $\%$ & 1,66 & 3,97 & $\mathrm{~kg} \cdot \mathrm{ha}^{-1}$ & 146 & 60 & 206 \\
\hline $\mathrm{Ca}$ & $\%$ & 1,88 & 0,48 & $\mathrm{~kg} \cdot \mathrm{ha}^{-1}$ & 165 & 7 & 172 \\
\hline K & $\%$ & 1,46 & 0,95 & $\mathrm{~kg} \cdot \mathrm{ha}^{-1}$ & 128 & 14 & 142 \\
\hline S & $\%$ & 0,77 & 0,67 & $\mathrm{~kg} \cdot \mathrm{ha}^{-1}$ & 68 & 10 & 78 \\
\hline $\mathrm{P}$ & $\%$ & 0,31 & 0,77 & $\mathrm{~kg} \cdot \mathrm{ha}^{-1}$ & 27 & 12 & 39 \\
\hline $\mathrm{Mg}$ & $\%$ & 0,31 & 0,33 & $\mathrm{~kg} \cdot \mathrm{ha}^{-1}$ & 27 & 5 & 32 \\
\hline $\mathrm{Na}$ & $\mathrm{mg} \cdot \mathrm{kg}^{-1}$ & 960 & 24 & $\mathrm{~g} \cdot \mathrm{ha}^{-1}$ & 8448 & 36 & 8484 \\
\hline $\mathrm{Fe}$ & $\mathrm{mg} \cdot \mathrm{kg}^{-1}$ & 93 & 95 & $\mathrm{~g} \cdot \mathrm{ha}^{-1}$ & 818 & 142 & 960 \\
\hline $\mathrm{Sr}$ & $\mathrm{mg} \cdot \mathrm{kg}^{-1}$ & 70 & 12 & $\mathrm{~g} \cdot \mathrm{ha}^{-1}$ & 616 & 18 & 634 \\
\hline $\mathrm{Mn}$ & $\mathrm{mg} \cdot \mathrm{kg}^{-1}$ & 56 & 41 & $\mathrm{~g} \cdot \mathrm{ha}^{-1}$ & 493 & 62 & 555 \\
\hline $\mathrm{Al}$ & $\mathrm{mg} \cdot \mathrm{kg}^{-1}$ & 39 & 6 & $\mathrm{~g} \cdot \mathrm{ha}^{-1}$ & 343 & 9 & 352 \\
\hline B & $\mathrm{mg} \cdot \mathrm{kg}^{-1}$ & 36 & 17 & $\mathrm{~g} \cdot \mathrm{ha}^{-1}$ & 317 & 26 & 343 \\
\hline $\mathrm{Zn}$ & $\mathrm{mg} \cdot \mathrm{kg}^{-1}$ & 10 & 40 & $\mathrm{~g} \cdot \mathrm{ha}^{-1}$ & 88 & 60 & 148 \\
\hline $\mathrm{Ba}$ & $\mathrm{mg} \cdot \mathrm{kg}^{-1}$ & 7 & 1 & $\mathrm{~g} \cdot \mathrm{ha}^{-1}$ & 62 & 2 & 64 \\
\hline $\mathrm{Cu}$ & $\mathrm{mg} \cdot \mathrm{kg}^{-1}$ & 2,87 & 4,36 & $\mathrm{~g} \cdot \mathrm{ha}^{-1}$ & 25,3 & 6,5 & 32 \\
\hline Mo & $\mathrm{mg} \cdot \mathrm{kg}^{-1}$ & 1,54 & 2,25 & $\mathrm{~g} \cdot \mathrm{ha}^{-1}$ & 13,6 & 3,4 & 17 \\
\hline $\mathrm{Ni}$ & $\mathrm{mg} \cdot \mathrm{kg}^{-1}$ & 0,33 & 1,10 & $\mathrm{~g} \cdot \mathrm{ha}^{-1}$ & 2,9 & 1,7 & 5 \\
\hline $\mathrm{Cd}$ & $\mathrm{mg} \cdot \mathrm{kg}^{-1}$ & 0,30 & 0,07 & $\mathrm{~g} \cdot \mathrm{ha}^{-1}$ & 2,6 & 0,1 & 3 \\
\hline $\mathrm{Cr}$ & $\mathrm{mg} \cdot \mathrm{kg}^{-1}$ & 0,22 & 0,22 & $\mathrm{~g} \cdot \mathrm{ha}^{-1}$ & 1,9 & 0,3 & 2 \\
\hline As & $\mathrm{mg} \cdot \mathrm{kg}^{-1}$ & 0,16 & 0,14 & $\mathrm{~g} \cdot \mathrm{ha}^{-1}$ & 1,4 & 0,2 & 2 \\
\hline $\mathrm{Se}$ & $\mathrm{mg} \cdot \mathrm{kg}^{-1}$ & 0,08 & 1,10 & $\mathrm{~g} \cdot \mathrm{ha}^{-1}$ & 0,7 & 1,7 & 2 \\
\hline Co & $\mathrm{mg} \cdot \mathrm{kg}^{-1}$ & 0,06 & 0,11 & $\mathrm{~g} \cdot \mathrm{ha}^{-1}$ & 0,5 & 0,2 & 1 \\
\hline
\end{tabular}


Megjegyzés: 8,8 t mellékterméssel és 1,5 t mag átlagterméssel számolvaFajlagos: $137 \mathrm{~kg} \mathrm{~N}$, $115 \mathrm{~kg} \mathrm{Ca}(161 \mathrm{~kg} \mathrm{CaO}), 21 \mathrm{~kg} \mathrm{Mg}(35 \mathrm{~kg} \mathrm{MgO}), 26 \mathrm{~kg} \mathrm{P}\left(60 \mathrm{~kg} \mathrm{P}_{2} \mathrm{O}_{5}\right), 95 \mathrm{~kg} \mathrm{~K}(114 \mathrm{~kg}$ $\left.\mathrm{K}_{2} \mathrm{O}\right), 52 \mathrm{~kg} \mathrm{~S}$

Az 1 t mag és a hozzátartozó melléktermés fajlagos tápanyagigénye kísérleti körülményeink között nagy volt, elsősorban a tág melléktermés/fötermés aránya miatt: $137 \mathrm{~kg} \mathrm{~N}, 115 \mathrm{~kg} \mathrm{Ca}(161 \mathrm{~kg} \mathrm{CaO}), 95 \mathrm{~kg} \mathrm{~K}(114 \mathrm{~kg} \mathrm{~K} 2 \mathrm{O}), 52 \mathrm{~kg} \mathrm{~S}, 26 \mathrm{~kg} \mathrm{P}$ $\left(60 \mathrm{~kg} \mathrm{P}_{2} \mathrm{O}_{5}\right), 21 \mathrm{~kg} \mathrm{Mg} \mathrm{(35} \mathrm{kg} \mathrm{MgO).} \mathrm{Amennyiben} \mathrm{csak} \mathrm{a} \mathrm{kombájnolt}$ magterméssel távozó elemek mennyiségeit vesszük figyelembe táblaszinten, amikor a melléktermés tömege a talajt gazdagítja, az $1 \mathrm{t}$ magterméstápelemtartalma ennek csak töredék : $40 \mathrm{~kg} \mathrm{~N}, 5 \mathrm{~kg} \mathrm{Ca}(7 \mathrm{~kg} \mathrm{CaO}), 14 \mathrm{~kg} \mathrm{~K}\left(17 \mathrm{~kg} \mathrm{~K}_{2} \mathrm{O}\right), 10 \mathrm{~kg} \mathrm{~S}, 12 \mathrm{~kg}$ $\mathrm{P}\left(27 \mathrm{~kg} \mathrm{P}_{2} \mathrm{O}_{5}\right), 5 \mathrm{~kg} \mathrm{Mg}(8 \mathrm{~kg} \mathrm{MgO})$. Adataink iránymutatóul szolgálhatnak a szaktanácsadás számára a repce elemszükségletének megállapításakor.

\section{Összefoglalás}

Mészlepedékes csernozjom vályogtalajon beállított szabadföldi kísérletben vizsgáltuk a NxCuxMo elemek közötti kölcsönhatásokat 2000-ben repcével. Termőhely talaja a szántott rétegben 3\% humuszt, 5\% körüli $\mathrm{CaCO}_{3}$-ot és $20 \%$ körüli agyagot tartalmazott. Talajelemzések alapján a terület jó $\mathrm{Ca}, \mathrm{Mg}, \mathrm{K}, \mathrm{Mn}$, kielégítő $\mathrm{Cu}$, valamint gyenge-közepes $\mathrm{P}$ és Zn ellátottságú volt. A talajvíz 13-15 m mélyen található, a terület aszályérzékeny. A kísérletet $4 \mathrm{~N}$ x $3 \mathrm{Cu}=12$ kezelés x 3 ismétlés = 36 parcellával állítottuk be osztott parcellás (split-plot) elrendezéssel. A $\mathrm{N}$ 0, 100, 200, $300 \mathrm{~kg} \cdot \mathrm{ha}^{-1}$, a $\mathrm{Cu} \mathrm{0,50,} 100 \mathrm{~kg} \cdot \mathrm{ha}^{-1}$ adagokat jelentett Caammóniumnitrát, illetve $\mathrm{CuSO}_{4}$ formájában. A kísérlet 5. évében a $15 \mathrm{~m}$ hosszú parcellákat megfeleztuik és $1 \mathrm{~m}$-es úttal elválasztottuk. A kísérlet sávos split-plot elrendezésüvé vált $4 \mathrm{Nx} 3 \mathrm{Cux} 2 \mathrm{Mo}=24$ kezelés x 3 ismétlés $=72$ parcellával. A 48 $\mathrm{kg} \cdot h a^{-1}$ Mo-t $\left(\mathrm{NH}_{4}\right) 6 \mathrm{Mo}_{7} \mathrm{O}_{24} \cdot 4 \mathrm{H}_{2} \mathrm{O}$ formában alkalmaztuk. A virágzás és az érés generatív fázisát aszály és depresszió jellemezte. Főbb eredmények

- A N-trágyázás hatására a magtermés $2 \mathrm{t} \cdot \mathrm{ha}^{-1}$-ról $0,8 \mathrm{t} \cdot \mathrm{ha}^{-1}$-ra esett. A szár tömege viszont $5 \mathrm{t} \cdot \mathrm{ha}^{-1}$-ról $8 \mathrm{t} \cdot \mathrm{ha}^{-1}$ fölé emelkedett a kedvezőbb, vegetatív fázisban érvényesülő N-hatások nyomán. Ebböl adódóan a harvest index 4,6-ról 13,0-ra tágult.

- Az elemtartalmak általában betöményedtek, dúsultak a növényi részekben. A N-kínálattal nőtt a $\mathrm{Na}, \mathrm{Fe}, \mathrm{Mn}, \mathrm{Zn}$, illetve mérséklődött a Ba koncentrációja a betakarításkori szalmában. Ugyanitt a $\mathrm{Cu}$ beépülését a $\mathrm{N}$ és a $\mathrm{Cu}$ adagolás egyaránt serkentette. Érvényesült a NxMo szinergizmus jelensége. A N és a Mo egyaránt dúsult a szárban mind a $\mathrm{N}$, mind a Mo kezelésekben. A magtermésben ez a NxMo kölcsönhatás szintén megnyilvánult.

- A magban dúsult a N, P, Mg, Zn, Cu, Mo, Se, Co aratáskor, meghaladva a szalmában mért koncentrációkat. A repce földfeletti biomasszájába a $10,4 \mathrm{t} \cdot \mathrm{ha}^{-1}$ légszáraz anyagba $206 \mathrm{~kg} \mathrm{~N}, 172 \mathrm{~kg} \mathrm{Ca}, 142 \mathrm{~kg} \mathrm{~K}, 78 \mathrm{~kg} \mathrm{~S}, 39 \mathrm{~kg} \mathrm{P}, 32 \mathrm{~kg} \mathrm{Mg}$ épült be. Kombájn aratásnál, amennyiben a melléktermés tömege leszántásra kerül, a tábláról eltávozó elemek mennyisége a töredékére esik vissza.

- Az 1 tonna magtermés képződéséhez kísérleti körülményeink között (melléktermés elemigénye nélkül) $40 \mathrm{~kg} \mathrm{~N}, 5 \mathrm{~kg} \mathrm{Ca}(7 \mathrm{~kg} \mathrm{CaO}), 14 \mathrm{~kg} \mathrm{~K}$ (17 kg 
$\left.\mathrm{K}_{2} \mathrm{O}\right), 10 \mathrm{~kg} \mathrm{~S}, 12 \mathrm{~kg} \mathrm{P}\left(27 \mathrm{~kg} \mathrm{P}_{2} \mathrm{O}_{5}\right), 5 \mathrm{~kg} \mathrm{Mg}(8 \mathrm{~kg} \mathrm{MgO})$ mennyiséget igényelt a repce. Adataink iránymutatóul szolgálhatnak a szaktanácsadás számára az őszi repce elemszükségletének megállapításakor.

Kulcsszavak: Nitrogén, réz és molibdén kölcsönhatások, tartamkísérlet, repce, mészlepedékes csernozjom talaj

\section{Irodalom}

BARANYAI F., FeKETE A. ÉS KovÁCS I. 1987. A magyarországi talaj tápanyagvizsgálatok eredményei. Mezőgazdasági Kiadó. Budapest.

BERGMANN, W. 1992. Nutritional disorders of plants. Gustav Fischer Verl. Jena

BuZÁs I., Fekete A., BuzÁs Iné, Csengeri Pné és Kovács Ané: 1979. Műtrágyázási irányelvek és üzemi számítási módszer. MÉM NAK. Budapest.

CSERHÁTI S. 1901. Általános és különleges növénytermelés. Czéh Sándor-féle Könyvnyomda. Magyar-Óvár.

EgNÉR, H., RIEHM, H. \& DomingO, W. R. 1960. Untersuchungen über die chemische Bodenanalyse als Grundlage für die Beurteilung des Nährstoffzustandes der Böden. II. K-Lantbr. Högsk. Ann. 26:199-215.

EÖRI T. 2001. A repce termesztése. Lucerna Bt. Fertöszéplak.

HORVÁth T. 2016. Az eredményes repcetermesztés sarokpontjai. Agrofórum. 8: 24-27.

ISO 11261. (1995): Soil Quality Determination of total nitrogen. Modified Kjeldahl method

KÁDÁR I., CSATHÓ P. 2017. A főbb makro- és mikroelemek közötti kölcsönhatások kísérletes vizsgálata. MTA TAKI. Budapest. 292 p.

KÁDÁR I., NÉMETH T., RÉTI Á. \& RADICS L. 2001a. A repce (Brassica napus L.) mütrágyázása karbonátos vályog talajon. I. Növénytermelés. 50:559-573.

KÁDÁR I., NÉMETH T. \& LUKÁCS DNÉ 2001b. A repce (Brassica napus L.) mütrágyázása karbonátos vályog talajon. II. Növénytermelés. 50:575-591.

KJELDAHL, J. 1891. Neue Methode zur Bestimmung des Stickstoffs in organischen Körpern. Zeitschr. f. analyt. Chemie. 22:366-382.

LAKANEN, E. \& ERVIÖ, R. (1971): A comparison of eight extractants for the determination of plant available microelements in soils. Acta Agr. Fenn. 123:223-232.

LÁNG G. 1976. Szántóföldi növénytermesztés. Mezőgazdasági Kiadó. Budapest

MÁtÉ A.-PEPó P. 2005. Repce. In: Növénytermesztéstan. 2. Ed: Antal J. Mezőgazda Kiadó. Budapest. 249-266 pp.

MÉM NAK. 1978. A TVG tápanyagvizsgáló laboratórium módszerfüzete. MÉM Növényvédelmi és Agrokémiai Központ. Budapest.

PRJANISNYIKOV, D.N. 1931. Csasztnoe zemledelije, Rasztenija polevoj kulturü. Szel'hozgiz. Moszkva-Leningrad.

TYURIN, I.V. 1937. Organicseszkoe vesesesztvo pocsvü. Szel'hozgiz. Moszkva 


\title{
Interactions between nitrogen, copper and molybdenum treatments on rapeseed (Brassica napus L.)
}

\author{
I. KÁDÁR \\ Institute for Soil Science and Agricultural Chemistry, Centre for Agricultural Research, \\ Hungarian Academy of Sciences, Budapest
}

\section{Summary}

Interactions between the elements $\mathrm{N}, \mathrm{Cu}$ and Mo were studied on rape in 2000 in a field experiment set up on chernozem loam soil with lime deposits. The ploughed layer of the soil contained 3\% humus, around 5\% $\mathrm{CaCO} 3$ and around $20 \%$ clay. Soil analysis showed that the area was well supplied with $\mathrm{Ca}, \mathrm{Mg}, \mathrm{K}$ and $\mathrm{Mn}$, had satisfactory $\mathrm{Cu}$ content, but was only poorly or moderately supplied with $\mathrm{P}$ and $\mathrm{Zn}$. The groundwater depth was 13-15 $\mathrm{m}$ and the area was prone to drought. The experiment was originally set up in a split-plot design with $4 \mathrm{~N} \times 3 \mathrm{Cu}=12$ treatments in three replications, giving a total of 36 plots. The $\mathrm{N}$ rates, applied as calcium ammonium nitrate, were $0,100,200$ and $300 \mathrm{~kg}$ ha-1 and the $\mathrm{Cu}$ rates, in the form of $\mathrm{CuSO} 4$, were 0,50 and $100 \mathrm{~kg}$ ha- 1 . In the 5 th year of the experiment the $15 \mathrm{~m}$ long plots were halved and the two half-plots were separated by a $1 \mathrm{~m}$ path. The experiment thus became a strip-split-plot design, consisting of $4 \mathrm{~N} \times 3 \mathrm{Cu} \times 2 \mathrm{Mo}=24$ treatments in three replications, giving a total of 72 plots. The $48 \mathrm{~kg}$ ha-1 Mo was applied in the form of $(\mathrm{NH} 4) 6 \mathrm{Mo} 7 \mathrm{O} 24 \cdot 4 \mathrm{H} 2 \mathrm{O}$. The generative phases of flowering and ripening were characterized by drought and depression. The main results were as follows:

- As a result of $\mathrm{N}$ fertilization, the seed yield fell from $2 \mathrm{t}$ ha-1 to $0.8 \mathrm{t}$ ha- 1 . However, the stem yield increased from 5 t ha-1 to $8 \mathrm{t}$ ha-1 due to the more favourable $\mathrm{N}$ effects in the vegetative phase. As a result, the harvest index increased from 4.6 to 13.0 .

- Most of the element contents became concentrated and enriched in the plant parts. The concentrations of $\mathrm{Na}, \mathrm{Fe}, \mathrm{Mn}$ and $\mathrm{Zn}$ increased with the $\mathrm{N}$ supply, whereas that of $\mathrm{Ba}$ decreased in the straw at harvest. Both $\mathrm{N}$ and $\mathrm{Cu}$ addition stimulated the incorporation of $\mathrm{Cu}$ in the straw. The phenomenon of $\mathrm{N} \times \mathrm{Mo}$ synergy was observed. $\mathrm{N}$ and Mo became enriched in the stem in both the $\mathrm{N}$ and $\mathrm{Mo}$ treatments. This $\mathrm{N} \times \mathrm{Mo}$ interaction was also manifested in the seed.

- Higher contents of $\mathrm{N}, \mathrm{P}, \mathrm{Mg}, \mathrm{Zn}, \mathrm{Cu}, \mathrm{Mo}, \mathrm{Se}$ and Co were recorded in the seed at harvest, exceeding the concentrations in the straw. A total of $206 \mathrm{~kg} \mathrm{~N}, 172$ $\mathrm{kg} \mathrm{Ca}, 142 \mathrm{~kg} \mathrm{~K}, 78 \mathrm{~kg} \mathrm{~S}, 39 \mathrm{~kg} \mathrm{P}$ and $32 \mathrm{~kg} \mathrm{Mg}$ was incorporated into the aboveground biomass of rapeseed, i.e. $10.4 \mathrm{t}$ ha-1 air-dry matter. In the case of combine harvesting, if the by-products are ploughed into the soil, the quantity of nutrients leaving the field falls to a fraction. 
- Under the conditions of this experiment, $40 \mathrm{~kg} \mathrm{~N}, 5 \mathrm{~kg} \mathrm{Ca}(7 \mathrm{~kg} \mathrm{CaO}), 14 \mathrm{~kg}$ $\mathrm{K}(17 \mathrm{~kg} \mathrm{~K} 2 \mathrm{O}), 10 \mathrm{~kg} \mathrm{~S}, 12 \mathrm{~kg} \mathrm{P}(27 \mathrm{~kg}$ P2O5) and $5 \mathrm{~kg} \mathrm{Mg}(8 \mathrm{~kg} \mathrm{MgO})$ was required for the production of $1 \mathrm{t}$ rapeseed. These data could serve as a guideline for the extension service in establishing the nutritional needs of winter rapeseed.

Keywords: Nitrogen, copper and molybdenum interactions, long-term experiment, oil rape, calcareous chernozem soil

\section{Tables and figures}

Table 1. Crop sequence in the long-term $\mathrm{N} \times \mathrm{Cu}$ experiment between 1988 and 2003 (Chernozem loam soil with lime deposits, Nagyhörcsök (1) Year. (2) Crop species. (3) Cultivar/hybrid. (4) Spring barley. (5) Winter wheat. (6) Winter barley. (7) Maize. (8) Triticale. (9) Potatoes. (10) Oats. (11) Rye. (12) Alfalfa. (13) Rape. (14) Poppy. (15) Sunflower.

Table 2. Effect of $\mathrm{N}$ fertilisation on the air-dry yield of rape on 26 June 2000 (Chernozem loam soil with lime deposits, Nagyhörcsök). (1) N levels, kg ha-1 year-1. (2) Stem, tha-1. (3) Pod, t ha-1. (4) Together, t ha-1. (5) Seed, tha-1. (6) Total, t ha-1. (7) By-products. (8) Main crop. (9) LSD5\% . (10) Mean.

Table 3. Effect of $\mathrm{N}$ levels on the element content of air-dry rape stems on 27 June 2000 (Chernozem loam soil with lime deposits, Nagyhörcsök). (1) N levels, kg ha-1 year-1. (2) LSD5\%. (3) Mean.

Table 4. Effect of $\mathrm{N} \times \mathrm{Cu}$ levels on the $\mathrm{Cu}$ and $\mathrm{Cd}$ contents of air-dry rape stems on 27 June 2000 (Chernozem loam soil with lime deposits, Nagyhörcsök). (1) $\mathrm{Cu}$ levels, kg ha-1. (2) N levels, kg ha-1 year-1. (3) LSD5\%. (4) Mean. Note: $\mathrm{Cu}$ fertilisation caused a significant rise in the $\mathrm{Cu}$ content of the seed yield from $3.90 \%$ to $4.96 \%$.

Table 5. Effect of $\mathrm{N} \times$ Mo levels on the $\mathrm{N}$ and Mo contents of air-dry rape stems on 27 June 2000 (Chernozem loam soil with lime deposits, Nagyhörcsök). (1) Mo levels, $\mathrm{kg}$ ha-1. (2) $\mathrm{N}$ levels, $\mathrm{kg}$ ha-1 year-1. (3) LSD5\%. (4) Mean. Note: The $\mathrm{N}$ content of the seeds was also significantly increased by Mo fertilisation.

Table 6. Mean element contents and element uptake of rape at harvest on 27 June 2000 (Chernozem loam soil with lime deposits, Nagyhörcsök). (1) Element symbol. (2) Unit. (3) Element content. (4) Stem+pod. (5) Seed. (6) Element uptake. (7) Together. Note: In terms of $8.8 \mathrm{t}$ by-products and $1.5 \mathrm{t}$ seed. 